\title{
Effects of quercetin and resveratrol on human vascular endothelial cell gene expression and endothelin secretion
}

\author{
Sonja Nicholson, Gregory Tucker and John Brameld \\ Nottingham University (Nutritional Sciences), Sutton Bonington, Leicestershire, UK
}

Epidemiological studies have shown an association between the intake of plant foods, particularly fruit and vegetables, and a decrease in CHD and other $\mathrm{CVD}^{(1)}$. These beneficial effects on cardiovascular health are suggested to be a result of the presence of polyphenols. Previous studies have shown that polyphenols are beneficial to cardiovascular health, particularly those present in red wines such as resveratrol and quercetin, which are thought to account for the beneficial effects of wine known as the 'French paradox'(2). Red wine polyphenols have been associated with reductions in the occurrence or severity of hypertension and are thought to regulate production of the vasoconstrictor endothelin-1 (ET-1) and the enzyme responsible for the production of the vasodilator NO, endothelial NO synthase (eNOS), but all studies to date have used supraphysiological concentrations. Cyclic strain and treatment with $\mathrm{H}_{2} \mathrm{O}_{2}$ are known to elevate the expression of ET-1 and eNOS in human umbilical vein endothelial cells (HUVEC) ${ }^{(3)}$. The aims of the study were to investigate: (1) whether physiological concentrations $(0.1 \mu \mathrm{M})$ of the red wine polyphenols quercetin and resveratrol have beneficial effects on ET-1 and eNOS mRNA expression and ET-1 secretion by HUVEC; (2) whether they alter the effects of $\mathrm{H}_{2} \mathrm{O}_{2}$ on ET-1 and eNOS mRNA expression.

HUVEC and culture media (EBM-2) were purchased from Lonza Group UK Ltd (Slough, Berks., UK) and an endothelin ELISA kit was purchased from Biomedica Gruppe (Vienna, Austria). HUVEC were treated with increasing concentrations of quercetin, resveratrol $(0-1.0 \mu \mathrm{M})$ or ascorbic acid $(0-0.3 \mu \mathrm{M})$ in the absence and presence of $\mathrm{H}_{2} \mathrm{O}_{2}(50 \mu \mathrm{M})$. Expression of eNOS and ET-1 mRNA was determined by quantitative RT-PCR and secretion of ET-1 protein into the media measured by ET-1 ELISA assay. Gene expression and ET-1 secretion data were analysed by two-way ANOVA using Genstat software (version 10; VSN International Ltd, Hemel Hempstead, Herts., UK). As expected, treatment of HUVEC with $50 \mu \mathrm{M}-\mathrm{H}_{2} \mathrm{O}_{2}$ significantly increased the expression of both ET-1 and eNOS mRNA. Treatment with either quercetin or resveratrol $(0.001-1.0 \mu \mathrm{M})$ resulted in dose-dependent increases in the expression of eNOS, but to a lesser extent than $\mathrm{H}_{2} \mathrm{O}_{2}$, and the effects were not additive $\left(P<0.001 ; \mathrm{H}_{2} \mathrm{O}_{2} \times\right.$ polyphenol interaction for both). In contrast, treatment with either quercetin or resveratrol $(0.001-1.0 \mu \mathrm{M})$ resulted in dose-dependent decreases in expression of ET-1, particularly in the presence of $50 \mu \mathrm{M}-\mathrm{H}_{2} \mathrm{O}_{2}\left(P<0.001 ; \mathrm{H}_{2} \mathrm{O}_{2} \times\right.$ polyphenol interaction for both). In agreement with the gene expression data $\mathrm{H}_{2} \mathrm{O}_{2}(50 \mu \mathrm{M})$ significantly increased ET-1 secretion into the media relative to controls (Table), while quercetin and resveratrol $(0.1 \mu \mathrm{M})$ both decreased ET-1 secretion in the absence of $\mathrm{H}_{2} \mathrm{O}_{2}(50 \mu \mathrm{M})$ and inhibited the stimulatory effect of $\mathrm{H}_{2} \mathrm{O}_{2}$ (Table).

Table. Effects of quercetin and resveratrol on ET-1 secretion by HUVEC in the absence and presence of $\mathrm{H}_{2} \mathrm{O}_{2}$

\begin{tabular}{|c|c|c|c|c|c|c|c|c|c|c|}
\hline \multirow{2}{*}{$\begin{array}{l}\text { Polyphenol treatment } \ldots \\
\mathrm{H}_{2} \mathrm{O}_{2}(50 \mu \mathrm{M})\end{array}$} & \multicolumn{2}{|c|}{ Control } & \multicolumn{2}{|c|}{ Quercetin $(0.1 \mu \mathrm{M})$} & \multicolumn{2}{|c|}{ Resveratrol $(0.1 \mu \mathrm{M})$} & \multirow[b]{2}{*}{ SED } & \multicolumn{3}{|c|}{$P$} \\
\hline & - & + & - & + & - & + & & $\mathrm{H}_{2} \mathrm{O}_{2}$ & Polyphenol & $\mathrm{H}_{2} \mathrm{O}_{2} \times$ polyphenol \\
\hline ET-1 (fmol/ml) & 4.32 & 6.01 & 3.68 & 4.75 & 3.46 & 4.51 & 0.11 & $<0.001$ & $<0.001$ & 0.002 \\
\hline
\end{tabular}

In conclusion, resveratrol and quercetin significantly altered the expression of genes important in cardiovascular health, including the response to $\mathrm{H}_{2} \mathrm{O}_{2}$. The mechanisms by which these polyphenols exert their effects on gene expression are largely unknown, but transcription factors such as NF- $\mathrm{KB}$ may play a role.

1. Brat P, George S, Bellamy A, Du Chaffaut L, Scalbert A, Mennen L, Arnault N \& Amiot MJ (2006) J Nutr 136, $2368-2373$.

2. Nicholson SK, Tucker GA \& Brameld JM (2008) Proc Nutr Soc 67, 42-47.

3. Liu JC, Chen JJ, Chan P, Cheng CF \& Cheng TH (2003) Hypertension 42, 1198-1205. 